\title{
Ethnobotany of Valuable Medicinal Plants Available in Chhattisgarh Plain Region of Balaghat District, Madhya Pradesh
}

\begin{abstract}
Background: Balaghat district of Madhya Pradesh is one of the largest tribal dominated district in Central India. Baiga and Gond are the main two tribes of the Baihar, Birsa, Paraswada, Langi, Kirnapur, Katangi, Balaghat, Waraseoni and Lalbarra tehsils of Balaghat district. These tribes have enormous knowledge about medicinal properties of the plant species available in natural ecosystems (forests and grasslands). Therefore, the study aimed to investigate the plants used by these tribes for seminal debility and other diseases.

Methods: Survey was carried out during 2019-20 in Biahar, Birsa, Paraswada, Langi, Kirnapur, Katangi, Lalburra and Waraseoni tehsils of the district Balaghat. Judgmental/purposive sampling method used to collect the required information from the tribes of the locality.

Result: Total 35 most important plants were used for curing various diseases and injuries. Along with their botanical description, we explained the method of intake of the plant medicines to cure the diseases. Around $39 \%$ of the plants used to cure seminal debility comes under herb category whereas shrub $(28 \%)$, climber $(11 \%)$, grass $(6 \%)$, twiner $(6 \%)$, small tree $(5 \%)$ and big tree $(5 \%)$. Whereas, $76 \%$ herbs utilized for curing other diseases, followed by shrub (18\%) and twiner $(6 \%)$.
\end{abstract}

Key words: Ayurveda, Ethnobotany, Seminal debility, Medicinal plants, Tribes.

\section{INTRODUCTION}

In India, references to curative properties of some herbs in the Rig Veda seem to be the earliest records of use of plants in medicine (Vedavathy, 2003). The identity of several plants referred to in the Suktas of the Rig Veda can be fixed with reasonable certainty, e.g. of Semal, Pithwan, Palash and Pipal. However, references to plants in the Rig Veda were very brief. More account that is detailed available in the Atharva Veda. The period of Rig Veda is estimated to be between 3500 and 1800 B.C. After the Vedas, there is no information on the development of this science in India for a period of about 1,000 years (Khare, 2007; Tripathi and Mishra, 1971).

Then appeared the two most important works on Indian system of medicine, the works of Charak and Susruta, namely, the charak-Samhita and Susruta-Samhita. SusrutaSamhita deals with about 700 drugs, some of these are not indigenous to India. With the passing of time, more and more plants found entry into native medicine, taking the number of Indian medicinal herbs to about 1,500 (Humaira et al., 2021; Balkrishna et al., 2019; Chandra et al., 2017; Aniwal et al., 2006; Katewa and Galav, 2005; Kunhikannan et al., 1993).

India has one of the richest ethno botanical traditions in the world, it has been estimated that about 7,000 species of the plants are used for medicine in India in the traditional system of medicine because plants form the main resources base of traditional medicine. Among the Indian system of medicine, Ayurveda, the most prevalent system in the country, uses about 700 species of plants, Unani 400 species and
Department of Agro-forestry, College of Agriculture, Jawaharlal Nehru Krishi Vishwa Vidyalaya, Jabalpur, Balaghat-481 331, Madhya Pradesh, India.

Corresponding Author: S. Sarvade, Department of Agro-forestry, College of Agriculture, Jawaharlal Nehru Krishi Vishwa Vidyalaya, Jabalpur, Balaghat-481 331, Madhya Pradesh, India.

Email: somanath553@gmail.com

How to cite this article: Bisen, N.K., Sarvade, S., Gaur, V.S. and Gautam, K. (2021). Ethnobotany of Valuable Medicinal Plants Available in Chhattisgarh Plain Region of Balaghat District, Madhya Pradesh. Indian Journal of Agricultural Research. DOI: 10.18805/ IJARe.A-5899.

Submitted: 23-08-2021 Accepted: 18-10-2021 Online: 18-11-2021

Aamchior Tibetan system about 300 species. The folklore system plans an important role in meeting the health care needs of the rural community in India and use more number of plants than in the India systems of medicine (Elakkiya et al., 2020; Malik et al., 2020; Jadhav et al., 2016; Kala, 2017 and Thakur et al., 2015).

The state of Madhya Pradesh situated between latitudes $17^{\circ}$ to $26^{\circ}$ and longitudes $74^{\circ}$ to $84^{\circ}$ with average elevation $50^{\circ} \mathrm{m}$ in the heart of India.

Balaghat district is in the southeastern portion of the state. Balaghat is situated between $21^{\circ} .19^{\prime}$ to $22^{\circ}$. $24^{\prime}$ North latitudes and $79^{\circ} .31^{\prime}$ to $81^{\circ} .33^{\prime}$ East longitudes with average elevation $288 \mathrm{~m}$. It is the fifth largest district in the State, occupying an area of $9229 \mathrm{Sq}$. Km. The forest area of district is $4997 \mathrm{Sq}$. Km constituting $54 \%$ of the total geographical 
area. Total population of district is about 17 lakhs out of which $22.5 \%$ are tribes. The districthas varying soil types, ranging from alluvial to medium and shallow black, mixed red and black, mixed red yellow and sandy loam. The annual rainfall is about $1600 \mathrm{~mm}$. Thus, the district comprises a rich flora consisting plants of medicinal and aromatic importance. The districtis blessed with large natural resources particularly for medicinal plants species available in the dense tribal in habited forests. Baiga and Gond are the main tribes of district Balaghat. These tribes mainly occur in Biahar, Birsa, Paraswada, Langi, Kirnapur, Katangi, Lalburra and Waraseoni tehsils. These tribes have vast knowledge of medicinal properties of the plant species available near their surroundings, which they use to treat the various ailments. It is observed that such knowledge acquired by a quack tribe during his lifetime goes in vain if it is not transferred to next generation (Deva and Shrivatsva, 1978; Sarvade, 2014; Sarvade et al., 2020).

\section{MATERIALS AND METHODS}

Study was carried out by scientists of College of Agriculture, Murjhad Farm Waraseoni tehsil of Balaghat district, Madhya Pradesh during 2019-20. Biahar, Birsa, Paraswada, Langi, Kirnapur, Katangi, Lalburra and Waraseoni tehsils of the district Balaghat were selected to conduct survey work. Judgmental/purposive sampling method was used for sample collection (Muller-Dombois and Ellenberg, 1974). Samples were collected from the forest and grasslands ecosystems of the study sites (Champion and Seth, 1968; Deva and Shrivastava, 1978; Mishra, 1968). Several plant species were observed to be used by local tribes to treat the seminal debility. Plant sample collection and identification was done by the scientists involved in the research. Plant specific information on ethno medicinal values was col- lected through discussion with the local tribe and users of the area.

\section{RESULTS AND DISCUSSIONS}

Total 35 medicinal plants were identified from the tribes of Balaghat district used for curing problems related to the seminal debility (18 species) and other diseases (17 species from 9 plant families) (Fig 1 and 3). Plant from the 14 families were recorded to cure seminal debility. Fabaceae family comprised 3 species, Malvaceae and Asparagaceae family comprised 2 species each and in rest of 11 family comprises 1 species each (Fig 1). Around 39\% of the plants used to cure seminal debility comes under herb category of plant habit. It was followed by shrub $(28 \%)$, climber $(11 \%)$, grass $(6 \%)$, twiner $(6 \%)$, small tree $(5 \%)$ and big tree $(5 \%)$ (Fig 2). Another study in Balaghat scientists reported $43 \%$ tree species followed by herbs $26 \%$, shrub $24 \%$ and climber $7 \%$ the total medicinal plants (Gwalwanshi and Bishwas, 2017).

Plants used for curing other diseases 17 species from 9 families were identified by the tribes of Balaghat. Among these families Asteraceae family was dominant with 5 plant species, followed by Malvaceae (2), Lamiaceae (2) and Convolvulaceae. Whereas rest 5 plant families comprised 1 species each (Fig 3). Herb category plants (76\%) were mostly utilized for curing other diseases, followed by shrub $(18 \%)$ and twiner (6\%) (Fig 4). Knowledge of ethnic healers on medicinal plants in Balaghat district was identified 33 plantsbelonging to 32 genera and 20 families (Gwalwanshi and Bishwas, 2016).

In one study in Balaghat 2011, identified 50 medicinal plant species from 50 genera and 31 families used to cure refractory diseases such as cancer, malaria, rheumatism, liver disorder and respiratory diseases (Jain et al., 2011).

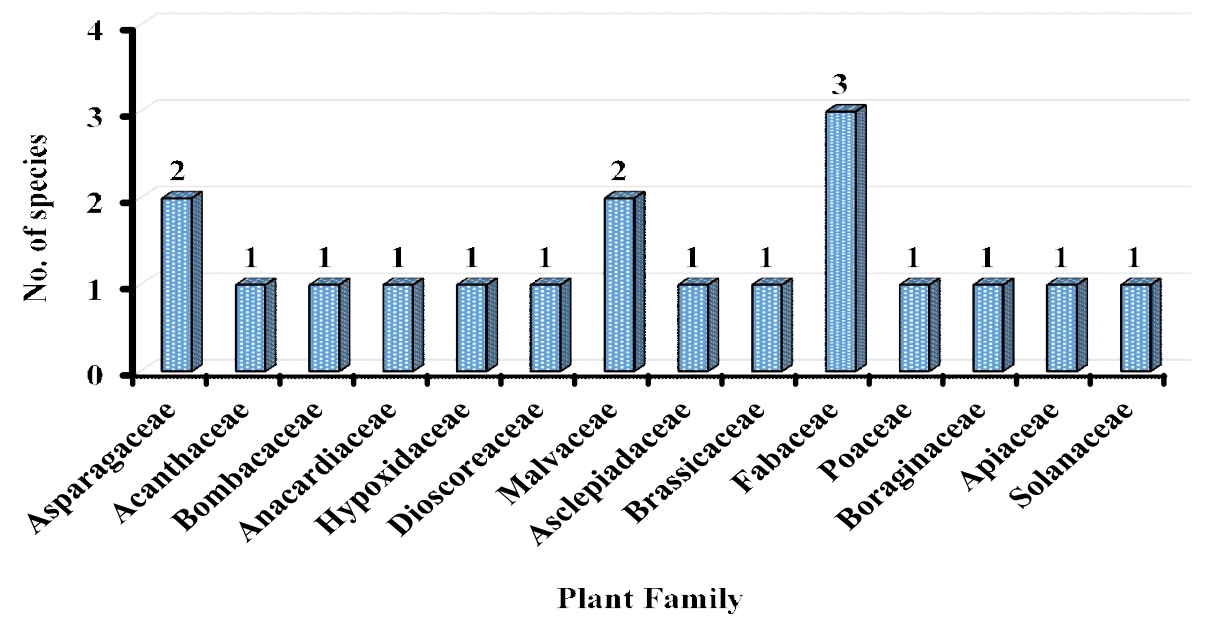

Fig 1: Plant species used by tribes of Balaghat to treat seminal disability 


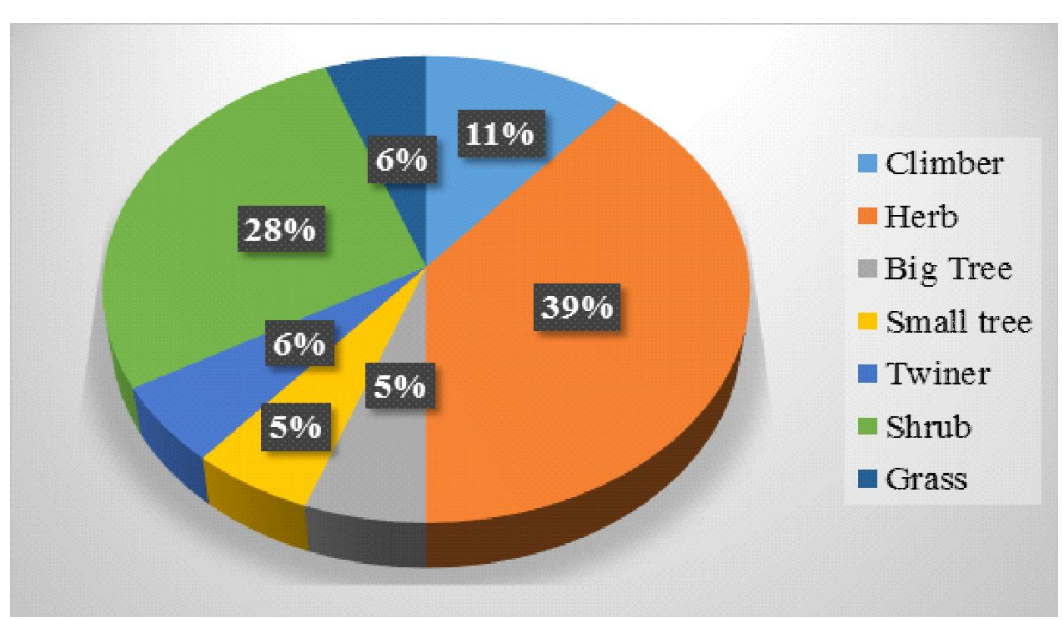

Fig 2: Habit of the plant species used to treat seminal disability.

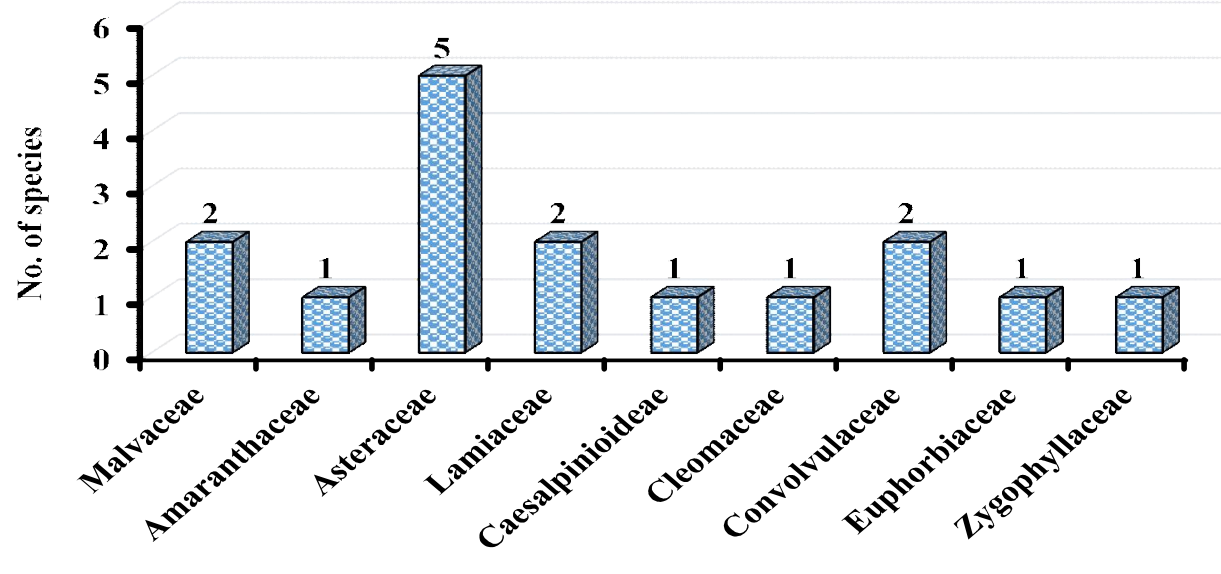

Plant Family

Fig 3: Plant species used by tribes of Balaghat to treat different diseases.

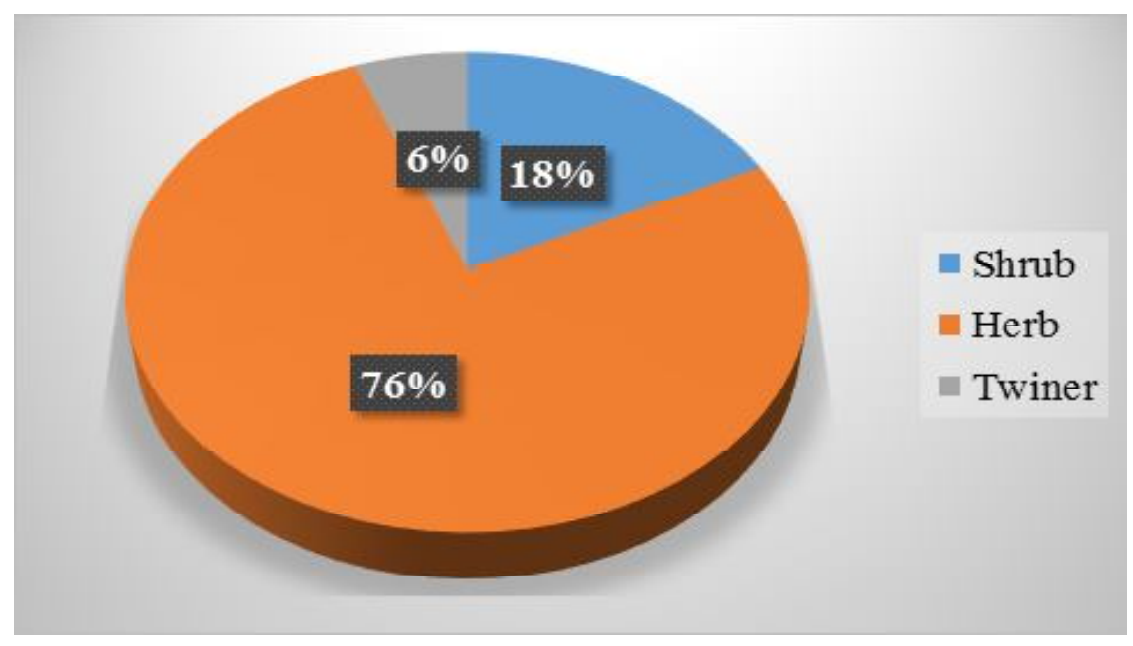

Fig 4: Habit of the plant species used to treat different diseases. 


\section{A. The following medicinal plants are found to be used in seminal debility by tribes of Balaghat District}

1 Botanical Name

Local name

Family

Habit

Part used

Use

Fruiting and Flowering season

Mode of regenerate

2

Botanical Name

Local name

Family

Habit

Part used

Use

Fruiting and Flowering season

Mode of regenerate

Botanical Name

Local name

Family

Habit

Part used

Use

Fruiting and Flowering season Mode of regenerate

4

Botanical Name

Local name

Family

Habit

Part used

Use

Fruiting and Flowering season

Mode of regenerate

5

Botanical Name

Local name

Family

Habit

Part used

Use

Fruiting and Flowering season Mode of regenerate

6

Botanical Name

Local name

Family

Habit

Part used

Use

Fruiting and Flowering season

Mode of regenerate

7

Botanical Name

Local name

Family
Asparagus racemosus Wild

Satawar

Asparagaceae

Climber

Flashy roots

About $50 \mathrm{gm}$. fleshy roots are given orally per day for a week.

June to December

by seeds / by tubers

Chlorophytum tuberosum Baker

Safed Musli, Mulsii Kand

Asparagaceae

Herb

Roots

Root powder fried in ghee and taken orally with diet at one day interval for the treatment of seminal debility.

June to October

By rhizome disc/by seeds

Asteracantha longifolia Nees

Talmakhana

Acanthaceae

A spiny herb

Seeds

About $10 \mathrm{gm}$ mature seeds are given orally with sugar or gur daily for 8 to 10 days

September to June

By seeds

Bombax ceiba $L$

Semal, Sawar

Bombacaceae

A tall deciduous tree

Young roots

Young roots of one year age plant are chewed twice a day for 3 to 4 days.

March to June

By seeds

Buchanania lanzan Spreng

Achar, Chirongi

Anacardiaceae

A medium sized tree

Seeds

Seeds, about $10 \mathrm{gm}$ are given daily with diet for the treatment of seminal debility

January to June

By seeds

Curculigo orchioides Gaertn

Kali musli

Hypoxidaceae

A small perennial herb

Roots

About 25 gm small pieces of roots are given orally with sugar or gur daily, for a week.

August to September

By seeds/rhizome discs.

Dioscorea hispida Dennst Schl.

Baichand

Dioscoraceae 
Habit

Part used

Use

Fruiting and Flowering season

Mode of regenerate

Botanical Name

Local name

Family

Habit

Part used

Use

Fruiting and Flowering season Mode of regenerate

9

\section{Botanical Name}

Local name

Family

Habit

Part used

Use

Fruiting and Flowering season

Mode of regenerate

10

11

12

Local name
Botanical Name

Family

Habit

Part used

Use

Fruiting and Flowering season

Mode of regenerate

Botanical Name

Local name

Family

Habit

Part used

Use

Fruiting and Flowering season

Mode of regenerate

Botanical Name

Local name

Family

Habit

Part used

Use

Fruiting and Flowering season Mode of regenerate

Botanical Name

Local name

Family

Habit

Part used

Use

Fruiting and Flowering season Mode of regenerate
A extensively prickly twiner

Tubers

Dried tuber chips are given as a special diet.

September to May

By rhizome.

Hibiscus lobatus (Murr) Kuntze.

Jungli Bhindi, Kamraj

Malvaceae

Slightly branched annual herb

Root and leaves

Roots are use in dysentery and stomachache, leaves paste used to cattle for anorexia

July to January

By seeds

Leptadenia reticulate $W \& A$

Jiwanti, Dodi mirch

Asclepiadaceae

A branched twining shrub

Root

Small pieces of roots are taken orally with milk.

August to October

By seeds

Lepidium sativum $\mathrm{L}$.

Chandvasure, Hallow

Brassicaceae

Cultivated herb

Seeds

Boil the seeds about $20 \mathrm{gm}$ and taken with sugar daily

November to February

By seeds

Mucuna pruriens (L.) D.C.

Kimach

Fabaceae

An annual climbing shrub

Seeds

Powder of seeds mixed with honey or ghee and given orally

October to February.

By seeds

Pueraria tuberosa D.C.

Bidarikand, PatalKumhda

Fabaceae

Tuberous herbaceous climber

Tuberous roots

Boiled tuber is eaten with sugar or Gur as a special diet to control the seminal debility.

April to June

By tuberous roots / By seeds.

Saccharum spontaneum L.

Kans

Poaceae

Erect tall grass with stout root stock

Roots

Juice of fresh roots taken orally

August to October

By seeds / By roots stock 
14

Botanical Name
Local name
Family
Habit
Part used
Use

Fruiting and Flowering season Mode of regenerate

15

16

17

18

Local name

Family

Habit

Part used

Use

Fruiting and Flowering season

Mode of regenerate

Botanical Name

Local name

Family

Habit

Part used

Use

Fruiting and Flowering season

Mode of regenerate

Botanical Name

Local name

Family

Habit

Part used

Use

Fruiting and Flowering season

Mode of regenerate

Botanical Name

Local name

Family

Habit

Part used

Use

Fruiting and Flowering season

Mode of regenerate

Sida acuta Burm f.

Bala, Kharenti

Malvaceae

Much branched subshrub

Fresh roots

Fresh roots are crushed, ground and mixed with sugar or gur and taken orally with diet.

August to January

By seeds

Cynoglossum lanceolatum Stapf \& Drummond

Balraj

Boraginaceae

Herb

Roots

Fresh roots are eaten with milk.

October to January

By Suckers / By seeds.

Flemingia bracteata L.

Bhainsa Toad

Fabaceae

Shrub

Root

Small pieces of young roots are eaten with gur or sugar.

October to December

By seed

Peucedanum dhana Ham.

Tejraj

Apiaceae

Herb

Root

Fresh roots are chewed with Piper betle.

October to January

By seed

Datura metel L.

Kala Dhatura

Solanaceae

A small shrub

Anthers

3-4 anthers of flower are eaten daily with mishri for a week.

August to January

By seed

\section{B. The following medicinal plants are used by tribes for treatment of various diseases.}

19

Botanical Name
Local name
Family
Habit
Part used
Use

Fruiting and Flowering season

Mode of regenerate

Botanical Name

Local name

Family
Abutilon indicum (L.) Sweet

Kanghi

Malvaceae

Small Shrub

Bark, root,leaves,seed and flower

Decoction of leaves used to treat fever, anti-inflammatory and in urinary troubles. Bark is astringent and diuretic. Roots are used as a nerve tonic and also used in piles. Flowers are used to increase semen in men. September to February

By seed

Achyranthes aspera Linn.

latjeera/andhijara

Amaranthaceae 


\section{Habit \\ Part used \\ Use}

Fruiting and Flowering season Mode of regenerate
Botanical Name

Local name

Family

Habit

Part used

Use

Fruiting and Flowering season

Mode of regenerate

Botanical Name

Local name

Family

Habit

Part used

Use

Fruiting and Flowering season Mode of regenerate

Botanical Name

Local name

Family

Habit

Part used

Use

Fruiting and Flowering season Mode of regenerate

Botanical Name

Local name

Family

Habit

Part used

Use

Fruiting and Flowering season Mode of regenerate

Botanical Name

Local name

Family

Habit

Part used

Use

Fruiting and Flowering season Mode of regenerate
A wild, perennial, erect herb

Whole plant

Ash of plant with honey twice a day used to treat cough. Seed are used as a tonic. Extraction of roots taken at night of menstrual disorders.

Root and stem ash is used for treatment of toothache and pyorrhea.

September to February

By seed

Ageratum conyzoides Linn.

Mahkua

Asteraceae

Annual herb

Seed, leaf and whole plant

Is used in piles, colic pain, boils, cough and fever. Seed are used as a tonic. January to March

Seed

Anisomeles indica Ktze

Bhandari

Lamiaceae

Perennial herb

Whole plant specially leavesand root

Has carminative, astringent and toxic properties. The essential oil of this plant is used in uterine affections. An infusion of the aromatic bitter leaves is in common use in affections of the stomach and bowels, ca tarrhal affections and intermittent fevers.

Throughout the year when enough water is available.

Seed

Blumea lacera DC.

kakronda, kakarchhidi

Asteraceae

Leafy annual herb

Leaf and flower

Is used in cases of dermatitis and its infusion is claimed to be very effective anthelmintic. The leaves are frequently used by the folk to check the profuse bleeding from the injured organs.

All year round

Seed

Cassia tora Linn.

Chakavad/chakra mard

Caesalpinioideae

Perennial herb/ subshrub

Seed, leaves, whole plant

Treats eye and skin diseases by its dry leaves. Treatment of gastrointes tinal disorders improves digestion and removes constipation. Seeds are rottened in curd and applied on leprotic skin

with lemon juice.

August to November

Seed

Cleome viscose Linn.

Hurhur/ Hulhul

Cleomaceae

Annual, sticky herb

Whole plant (seeds, leaves and roots)

Corrects digestive problems of animals by used of its seeds.

July to October

Seed 
Ethnobotany of Valuable Medicinal Plants Available in Chhattisgarh Plain Region of Balaghat District, Madhya Pradesh

26

Botanical Name

Local name

Family

Habit

Part used

Use

as laxative and brain tonic

Fruiting and Flowering season

Mode of regenerate

27

Botanical Name

Local name

Family

Habit

Part used

Use

Fruiting and Flowering season

Mode of regenerate

28

29

Botanical Name

Local name

Family

Habit

Part used

Use

Fruiting and Flowering season

Mode of regenerate

Botanical Name

Local name

Family

Habit

Part used

Use

Fruiting and Flowering season

Mode of regenerate

30

Botanical Name

Local name

Family

Habit

Part used

Use

Fruiting and Flowering season

Mode of regenerate

31 Botanical Name

Local name

Family

Habit

Part used
Convolvulus microphyllus Sieb.

Sankhpushpi

Convolvulaceae

Fulvous hairy herb

Whole plant (seeds, leaves and roots)

Is an important indigenous drug (young leaf, flower and seed) used

October to December

Seed

Euphorbia thymifolia Linn.

Chhotidudhi

Euphorbiaceae

Softly hispid prostrate herb

Latex, Seed and leaves

Yields aromatic and astringent leaves and seeds used in indigenous medicine for diarroea and dysentery in children. The milky juice is a violent purgative used to cure ringworm

Whole year

Seed

Ipomoea pestigridis Linn.

Ghiabati, Panch-patri.

Convolvulaceae

Twining, herbaceous, hairy, annual vine

Root

The root of this plant is usedas a perfect laxative and leaves are used to heal Sores and Boils

September to December

Seed

Ocimumcanum Sime

Ramtulsi, rantulsi, vantulsi

Lamiaceae

Herb

Leaves and seed

Provides leaves and seeds for curing liver and asthmatic problems and dysentery. The decoction of leaves is used in malarial and intermittent fevers. The roots along with the bark of neem (Azadirachta indica) in the form of poultice are used in cases of scabies and ringworm.

August - November

Seed

Sida cordifolia Linn.

Bala

Malvaceae

perennial subshrub

Root

Provides roots exhibiting astringent, diuretic and stimulant curing urinary troubles, strangury and hematuria, hemiplegia sciatica and facial paralysis. Roots are used in combination with asafetida and rock salt. Powdered roots are given with milk in leucorrhoea and micturition. Seeds are aphrodisiac and also used in colic pains.

September to December

Seed

Sphaeranthus indicus Linn.

Mundi, gorakhmundi

Asteraceae

Herb

Root, Leaf and flower 
Use

Fruiting and Flowering season Mode of regenerate

\section{Botanical Name}

Local name

Family

Habit

Part used

Use

Fruiting and Flowering season Mode of regenerate
Botanical Name

Local name

Family

Habit

Part used

Use

Fruiting and Flowering season Mode of regenerate

Botanical Name

Local name

Family

Habit

Part used

Use

Fruiting and Flowering season

Mode of regenerate

Botanical Name

Local name

Family

Habit

Part used

Use

Fruiting and Flowering season

Mode of regenerate
Provides the root decoction for treatment of rheumatism and leaf paste for ringworm. The decoction of flowers heads along with honey is re garded as blood purifier and general tonic.

November to March

Seed

Spilanthes acmella Murr.

Akarkara

Asteraceae

Herb

Flower and leaves

Relieves toothache through chewing its pungent flower heads. Poor people chew its seeds instead of pepper to provoke salivation in their dry mouth. The plant is sometimes administered to women after child birth. March- April

Seed

Tribulus terrestris Linn.

Chhotagokhru

Zygophyllaceae

Annual Herb

Whole plant

Possesses fruits, which help remove kidney stones. Decoction of whole plant is given with almonds in impotency. It is regarded as cooling, di uretic tonic and aphrodisiac.

August to October

Seed

Vernonia cinerea (L) Less

Sahadevi

Asteraceae

Annual herb

Whole plant

Decoction of plant given in diarrhea, stomachache and for cough and colic Throughout the year

Seed

Xanthium strumarium Linn.

aadha-shishi

Asteraceae

Annual herb

Seed

Possesses seeds which cure a migraine pain, adha-shishi.

August to November

Seed

\section{CONCLUSION}

The research workers in Botany, Ayurveda, Chemistry, herbal practitioner, students as well as sufferer will find this type of study useful. Balaghat district of M.P. state, blessed with natural vegetation consisting of a large number of important medicinal plants in the post. Due to the human intervention most of these valuable plants are in the path of threatened category. If proper measures are not taken for the conservation of these valuable plant species, these species will be extinct in a near future.

\section{ACKNOWLEDGEMENT}

The authors are thankful to the Dean, College of Agriculture,
Balaghat for encouragement to prepare this manuscript. Authors also thankful to the Forest officers of the Balaghat Division and the local inhabitants for their help during the field work.

\section{REFERENCES}

Aniwal, P.N., Bellurkar, C.M., Bhosale, P.B. (2006). Use of indienous medicinal plants forrespiratory disorders. J. Daiying, Foods and H.S. 25(3/4): 218-223.

Balkrishna, A., Mishra, R.K., Srivastava, A., Joshi, B., Marde, R., Prajapati, U.B. (2019). Ancient Indian rishi's (Sages) knowledge of botany and medicinal plants since Vedic period was much older than the period of Theophrastus, a case study who was the actual father of botany? International Journal of Unani and Integrative Medicine. 3(3): 40-44. 
Ethnobotany of Valuable Medicinal Plants Available in Chhattisgarh Plain Region of Balaghat District, Madhya Pradesh

Champion, H.G., Seth, S.K. (1968). A Revised Survey of the Forest Type of India. Managers of publications. Govt. of India Press, Delhi 6.

Chandra, S., Kamboj, M.L., Kumari, A., Kumar, A., Rather, H.A. (2017). Potentiating immunity of dairy animals during transition period throughherbs - A review. Agricultural Reviews. 38(4): 297-303.

Deva, S., Srivastava, M.M. (1978). An ecological study of the vegetation of Golatappar Swamp, Dehradun. Indian Journal of Forestry. Indian J. Forestry. 1(1): 45-52.

Elakkiya, V., Krishnan, K., Bhattacharyya, A., Selvakumar, R. (2020). Advances in Ayurvedic medicinal plants and nano-carriers for arthritis treatment and management: A review. Journal of Herbal Medicine. 24: 1-90.

Gwalwanshi, D.R., Bishwas, A.J. (2016). Some unique traditional knowledge (ethno medicine) of ethnic healers of Balaghat district, Madhya Pradesh. Madhya Bharti Journal of Science. 60(1): 1-5.

Gwalwanshi, D.R., Bishwas, A.J. (2017). Documentation of ethnoveterinary medicinal flora of Balaghat district, Madhya Pradesh, India. Int. J. Res. Ayurveda Pharm. 8(2): 279284.

Humaira, Pant, S., Dar, A.R., Akhter, A.,Wani, M.R. and Shah, N.H. (2021). Diversity and utilization of medicinal flora of Baba Ghulam Shah Badshah University Campus Rajouri Jammu and Kashmir, India. Indian Journal of Agricultural Research. 55(1): 1-12.

Jadhav, R., Sharma, Y.P., Sarvade, S. (2016). Growth and yield of Malaxis acuminata D. Don as influenced by type of planting material. Environment and Ecology. 34(4A): 1935-1940.

Jain, S.P., Shrivastava, S., Singh, J., Singh, S.C. (2011). Traditional phototherapy of Balaghat district, Madhya Pradesh, India. Indian Journal of Traditional knowledge.10(2): 334-338.

Kala, C.P. (2017). Traditional health care systems and herbal medicines. European Journal of Environment and Public Health. 1(1): 03.
Katewa, S.S., Galav, P.K. (2005). Traditional herbal medicines from Shekhawati region of Rajasthan. Indian Journal of Traditional Knowledge. 4(3): 237-245.

Khare, C.P. (2007). Indian Medicinal Plants-An Illustrated Dictionary. Springer-Verlag Berlin/Heidelberg, New Delhi-India. 812p.

Kunhikannan, C., Varghese, M., Totey, N.G., Bisen, S.S., Khawarey, K.N. (1993). Plant diversity in and around Tadoba Lake, Maharashtra. Indian J. Trop. Biod. 1(1): 63-72.

Malik, A., Sehrawat, K., Ahlawat, A. and Sehrawat, A.R. (2020). A comparative biochemical evaluation of in vivo and in vitro propagated Alhagim aurorum: an important medicinal plant. Legume Research. 43(5): 627-633.

Misra, R. (1968). Ecology Work Book. Oxford and IBH Publishing Co. Calcutta.

Mueller-Dombois, D., Ellenberg, H. (1974). Aims and Methods of Vegetation Ecology. John Wiley, New York, pp. 547.

Sarvade, S. (2014). Agroforestry refuge for biodiversity conservation. International Journal of Innovative Research in Science and Engineering. 2(5): 424-429.

Sarvade, S., Shrivastava, A.K., Rai, S.K., Bisen, S., Bisen, U., Bisen, N.K., Agrawal, S.B., Mohammad Imran Khan. (2020). Socioeconomic study of farming communities, their knowledge on climate change and agroforestry systems in the cluster of villages of Chhattisgarh plain region, Madhya Pradesh. Journal of Pharmacognosy and Phytochemistry. 9(1): 2158-2166.

Thakur, U., Dutt, B., Sarvade, S., Sharma, K.R. (2015). Effect of FYM doses and plant spacing on production of Oenothera biennis L. Indian Journal of Ecology. 42(2): 359-362.

Tripathi, R.S., Misra, R. (1971). Phytosociological studies of the crop-weed association at Varanasi. J. Ind. Bot. Soc. 50: 142-152.

Vedavathy, S. (2003). Scope and importance of traditional medicine. Indian Journal of Traditional Knowledge. 2(3): 236-239. 